\title{
Insulin-Like Growth Factor
}

National Cancer Institute

\section{Source}

National Cancer Institute. Insulin-Like Growth Factor. NCI Thesaurus. Code C20442.

Bound to IGFBPs in the circulation, Insulin-Like Growth Factors (IGFs, Somatomedins) are a family of extracellular signaling peptides (potential autocrine ligands) involved in mediation of growth hormone action, stimulation of insulin action, and growth and development. The three main somatomedins are Somatomedin C (IGF1), Somatomedin A (IGF2), and Somatomedin B. Single chain IGFs I and II share about $47 \%$ amino acid homology with insulin (INS) and 31\% with relaxin. 